Characteristics of the VAT in Albania

\author{
Mikel Alla \\ PhD Cand. \\ Tax auditor at Regional Tax Directorate of Elbasan, Albania. \\ Lecturer of Finance at University "Aleksander Xhuvani" of Elbasan, Albania. \\ mikel.alla@yahoo.com
}

\begin{abstract}
The value added tax (taxe sur la valeur ajoutee - TVA) was "invented" by a finance expert of France called "Maurice Laure" (1917-20 April 2001). The system of "Laure" is designed to April 10, 1954. He "invented" a tax on consumption, which was called the VAT (TVA). His idea was quickly adopted because it compels taxpayers at all levels of the production process, for self-management and self-calculating the tax, instead of putting the burden on sellers, or the tax authorities make the tax assessments. The tax legislation for the VAT in Albania has changed constantly. The VAT in Albania is regulated by the Law No. 7928 dated 27.04.1995 "On the VAT". This law was amended to date from about 30 other laws . in the design of the fiscal policy of Albania , are taken into consideration the behavior of taxpayers and their ability to the tax evasion. Albanian state is trying to harmonize the fiscal legislation with those of the other countries of the European Union. This paper aims to show the main characteristics of the VAT in Albania. At the end of this paper, I will give my conclusions of the issue .
\end{abstract}

Keywords: vat, vat law, taxpayer.

\title{
Introduction
}

Value added tax (Taxe sur la valeur Ajoutee-TVA) is "invented" by a finance expert in France called "Maurice Laure" (191720 April 2001). in 1954, he "invented" a tax on consumption, which was called VAT (TVA). His idea was quickly adopted because it compels taxpayers at all levels of the production process for self-management and self-calculation of the tax, instead of putting the burden on the seller or require that the tax assessment be done by tax authorities.

The "Laure" system dates back to April 10, 1954 and initially affect only large enterprises. in 1960 success of the VAT in France, urged EU countries to adopt the VAT replacing their systems of taxation. in 1967, amended Directives 1 and 2 including and adapting, the VAT to the taxation system of the European member states. Then, was implemented in Brazil in 1967 at all levels of transactions, extending over the years 1970 to 1980 in 63 countries. Since 1990, more than 130 industrialized countries and developing countries in the world, that apply value added tax, that pay about 4 billion people (customers), with a value $\$ 18$ billion or $25 \%$ of total of tax revenue.

On 17 May 1967 adopted a law is unique and a general law for all EU countries, called Directive 6 (77/388/CEE). This directive has established unique rules about:

- Scope of application,

- Territory

- The taxable value

- Moment of supply

- Crediting.

The VAT in Albania currently is sanctioned by law no. 7928 dated 27.04.1995 "On Value Added Tax". Implementation of VAT and replacement of the turnover tax begins in July of 1996. Standard tax rate was $12.5 \%$ and subject to this tax, were, all taxpayers that realize an annual turnover greater than 2 million leks. Until June 1996, is applied the turnover tax, sanctioned by the Law no. 7676 dated 03.03.1993 "On the turnover tax." The turnover tax paid on all categories of production, imports and services. The turnover tax was $18 \%$. The VAT law is subjected to continuous changes. Changes in VAT law began in October 1997 after the pyramid scheme crisis, with replacement of tax scale with $12.5 \%$ standard tax rate of $20 \%$, which is in force today. in January 1998 the VAT registration threshold is made for those entities that realize an annual turnover greater than 5 million leks. From 1 January 2001, the VAT registration threshold becomes 8 million leks and again in February 2010 boundary changes, and decrease to 5 million leks. The aim was to increase the collection of 
this type of tax base by expanding taxable activities. Also reduction in the VAT registration threshold introduces the concept of fair treatment of businesses and makes it more difficult to hide financial data helping at the junction of data to the TAX CRM system. in Albania, currently, this tax rate has two levels; $0 \%$ for exports and international transport of passengers and goods and $20 \%$ for all other taxpayers.

The value added tax is an indirect consumption tax, which basically is levied on the "value added" to each economic phase of the chain of production-consumption. The tax base is the personal consumption of individuals, as measured by the price paid for goods and services. The VAT may be calculated through different methods: addition, sales-subtraction, and creditinvoice. in Albania is used the method of credit-invoice. Under the credit-invoice method, the taxpayer calculates the tax due within a tax period. This is the difference between the tax debit for taxable sales (the sum of the debit as stated in the invoices "output tax liability") minus the credit for taxable purchases ("input credits"). So, at the end of a reporting period, the albanian business calculates its tax liability by subtracting the cumulative amount of VAT stated on its purchase invoices from the cumulative amount of VAT stated on its sales invoices.

\section{Characteristics of the VAT in Albania}

The VAT is a tax on consumption. So, the VAT is carried to the consumer and it is the latter that pays this tax to the state budget. Therefore, this type of tax is included in the category of indirect taxes. VAT does not burden business. Tax on consumption means that the state taxes in fact, the final consumption of goods and services, while sellers of goods and services are themselves agents of collecting this tax from final consumers. So the real payers of VAT are the final consumers of goods and services. Following the movement of goods from the first link of the economic chain, which is the processor and producer of raw materials and to the retail trade network, it became very clear who is the real payer of this tax. All actors participating, from the manufacturer to the retailer have an obligation to calculate VAT on turnover made, but simultaneously calculate VAT for purchases made. Only the final consumer, is he pay the VAT to the extent of the tax rate, and just for the fact that he can not recover or be credited further, for the value of the tax credit.

The VAT is collected from taxpayers. The VAT is collected through a system of payment by businesses. The payable VAT is calculated as the difference of VAT on sales, the VAT on purchases. So VAT is a tax on the price difference (margin), which in fact, the final consumer pays.

The VAT is a neutral tax. The neutrality has to do with the balance of this type of tax in the taxpayer's financial situation. On the one hand taxpayers collect VAT from their customers which represents one side of the balance sheet, and on the other side of the balance sheet, they pose the VAT paid and credited to their purchases and VAT to be paid on account state. Consequently inflow and outflow is the same. The only exceptional cases are those taxpayers that buy goods and services with VAT at a greater extent or smaller than the VAT they collect when sell these goods and services. Exceptional case in Albania are exporting entities that buy goods with VAT 20\% and sell these goods abroad with $0 \%$ in pursuance of the VAT law. But even in this case VAT can win the quality of neutrality, if the VAT on the purchase of goods and services that respond to taxable supplies (exports) at $20 \%$ is reimbursed by the state. Another case in Albania (it was up in April 2014), for taxpayers (independent occupations and professions) which provide health services (dentists, laboratory technicians, etc.). As they buy goods with VAT at $20 \%$, and sell services at the level of $20 \%$. But even in this case VAT can win the quality of neutrality, if the VAT on the purchase of goods and services that respond to taxable supplies (exports) reimbursed to the extent of $10 \%$ by the state. Even in other cases when supplies are exempt from VAT, and the taxpayer, buys goods with VAT, the lawmaker has provided that in such cases, purchases with VAT, which serve to exempt supplies shall be considered as purchases exempt from VAT. Thereby losing the right to be credited, in this case, creates a kind of neutrality.

The VAT is a horizontal tax in Albania. Horizontal equity of the tax systems of those countries applying VAT, consists in that all taxpayers of certain categories in the same circumstances should have the same treatment. The VAT does not take into account the economic situation of the final consumer, so the VAT is not applied taking into account the income received by him or economic level of his family. The VAT is fixed and does not vary in relation to the implementation of customer revenue. Despite the disposable income, a final consumer, when presented in the market, it is before a price of a product that is the same for all clients or customers and applied VAT on these prices is the same.

The VAT is an indirect tax. The payment of this tax is done indirectly in the state budget. This tax is collected and paid by the "taxable persons", that are also the "legal payers" of this tax. So in some way they are taxpayers that pay VAT in the budget, that collect VAT from the final customers also called the "real payer". So, taxpayers are somehow "legal representative" of consumers for the declaration and payment of the VAT. Why such a way of paying the VAT? As it would 
be impossible to manage the VAT payments of consumers through the bank counters and branches of taxes every day. Also it would be impossible to manage, control and monitor the accuracy of payments of the VAT for each final consumer.

The VAT is self-declarative. The method of declaration and payment of VAT is based on this principle. All VAT taxpayers, declare and pay the VAT, within the set deadline (In Albania, this term is up on 14 of the next month), all supplies (sales) of goods or services carried out for a taxable period (in Albania is calendar month). The declaration made by the free will of the taxpayer based on real supplies made by him. This makes it a modern tax versus other types of taxes. VAT promotes self-assessment. The taxpayer, who is a link in the long commerce chain, files a tax return at the tax office (or by mail), and sends his payment to the tax administration. Also, VAT promotes self-enforcement because "businesses can claim a credit against their tax bill only if another business has previously paid tax on the sale"

VAT is a general tax. It applies, in principle, to all commercial activities including production and distribution (marketing) of goods and services, unless the cases exempted by law.

VAT ensures transparency in an economic cirkuit, because every payment makes with tax bill.

\section{The VAT in Albania and the legal framework}

Referring to the VAT Law No. 7928, dt. 27.04.1995, undergo to the application of VAT:

1. Supplies of goods

2. Supply of services when they:

a) carried out against payment,

b) by a taxable person,

c) as part of the economic activity of a taxable person,

d) in the territory of the Republic of Albania,

3. Imports of goods in the territory of the Republic of Albania.

Who is a taxable person?

The term "taxable person", used in the Albanian law, shall mean the person who performs operations within his s economic activity within the scope of application of VAT. Taxable person may be:

1. The legal person

2. Physical person

3. Individual

4. Institution

5. Central public institution or local public institution.

In the sense of Article 2 of the law, taxable persons are those persons that:

- are required to be registered (Article 3-6) or

- are registered but have not yet been de-registered (Article 7).

Registration of taxable person.

Registration is mandatory. When?

The obligation to register as a taxable person (the VAT) is:

- for new enterprises, within 15 days from the date of commencement of its economic activity, when its circulation performed or will be performed is greater than the minimum limit of registration. It is currently 5 million leks.

- for existing enterprises, within 15 days after the end of the calendar year, if the turnover this year exceeded the minimum limit of registration.

- for importers does not matter limit of 5 million. They are obliged to register despite the turnover.

VAT registration threshold. 
In Albania, the VAT registration threshold is a turnover of 5 million leks. Taxpayers, that, realize a turnover above this limit are obliged to register for the VAT regardless of their status.

Deregistration.

The person who does not meet with the conditions for being registered may request deregistration within 15 days after completion of its activities (Article 7). This thing happens with the:

- Completion of activity

- Reducing the turnover under 5 million leks

- Giving up of the right to be registered.

Each of the following changes require cancellation of existing registration:

- Closure of economic activity.

- Sale of economic activity.

- Union or amalgamation to perform an economic activity previously carried out by a taxable person.

Moment of supply (Article 13)

The Supply moment is considered the moment when it is mandatory to issue the tax invoice.

When will be issued the tax invoice of VAT? VAT invoice must be issued when:

- The goods are delivered

- Services are performed

- Exception to this rule is the case when the supplier of the goods or service collects a fee before that, of goods delivered or services are performed by him. in this case the supplier is obliged to issue a VAT invoice at the time when payment is made by him.

Importing goods is deemed accomplished at the time predicted that defines the customs code, so then where the import is deemed accomplished. "Release date" is the date when the goods 'released' by customs.

\section{Place of supply}

Thr place of supply of goods is where the goods are delivered or made available by suppliers. If the elaboration or the making available includes transportation of goods, the place of supply of goods is the palce where the transportation begins. So, the place is where:

o goods delivered

o made available by the supplier

o begins transporting goods.

The taxable value

The taxable value of a taxable supply, is the total amount in value or nature to be paid for supply, by any person. The total amount includes any tax and fees paid or payable for the supply, or because of supply, excluding the value added tax. It is the value on which the tax rate of VAT is applied.

Tax rate.

Albania applies two tax rate:

- The standard rate of $20 \%$,

- The rate of $0 \%$.

Standard rate applies to all supplies of goods and services and imports of goods.

Reduced tax rate of $0 \%$, applies with respect to:

- Goods that are exported from the territory of the Republic of Albania;

- Supplies of services outside the territory of the Republic of Albania by a taxable person, the place of economic activity, of which, is in Albania; 
- Supplies of goods and services in connection with the international transport of goods or passengers.

- Supplies of goods and services in relation to commercial or industrial activities in the sea.

Crediting of VAT

Crediting of VAT is the amount of VAT thst taxable person pays at the time he purchases goods or services within the country, and the amount of VAT he has paid for imports, with the the condition that, these supplies serve only to the taxable supplies, that will make the taxable person. Tax credit for a taxable period is the total of VAT applied in relation to:

- All taxable supplies made to a taxable person during the tax period by other taxable persons.

- All imports of goods made by a taxpayer during the the tax period.

Refund of VAT

Pursuant to Article 50 of Law No. 7928, dated 27.4.1995 "On value added tax" and Law No. 9920, dated 19.5.2008 "On Tax Procedures in RA", the taxable person shall be entitled to seek reimbursement of VAT, when he carried a refundable VAT over 3 (three) consecutive months (every month has resulted refundable VAT) and when this amount is greater than 400,000 ALL. When a taxpayer meets the above conditions, he completes the form "Request for Refund" and sends it to the respective Regional Tax Directorate. Refund of VAT, can be performed with the following three forms:

a) by transferring the amount overpaid to the account of the taxpayer.

b) by transferring the overpaid amount on account of payment of other obligations of taxpayer.

c) by transferring the amount overpaid, with the consent of the taxpayer, on account of payment of future tax liabilities.

Obligations of the taxable person.

A person, that with the his economic activity, included in the scope to VAT, should:

- register,

- issue the tax invoice for supplies made by him,

- keep records for the VAT,

- declare with the VAT form.

Tax assessments

Tax assessment is the calculation that makes tax administration, the amount of tax liability and administrative penalties and interest for late payment that a taxpayer is obliged to pay. Tax authorities have the right to assess the VAT when:

0 a person does not make the statement in that form determined by law;

0 a person requires that the amount of VAT shown as payable in a statement, should be changed because of a error or omission;

o estimate that the amount of VAT shown as payable to a statement made by a taxable person is less than the amount that should have been reflected as payable in that statement;

0 appreciate that, for any reason the amount of VAT is payable by a person to the state, and is not paid.

Appeal procedure

Every person has the right to complain the results of tax assessment made by the tax authorities.

1. The first degree of appeal (administrative) is the Directortorate of Appeal, at the General Directorate of Taxation.

2. The second degree of appeal is the court.

\section{Conclusions}

The VAT has these features:

the VAT is a tax on consumption

the VAT is a neutral tax,

the VAT is a horizontal tax, 
the VAT is self-declarative,

the VAT promotes self-enforcement.

Since, the VAT is a tax that contributes sufficiently to the Albanian budget, the VAT law should treat accurately and indisputably all issues related to the operation of this tax. As a result, the Albanian lawmaker should apply the reduced rates of the VAT for such categories.

The VAT law should not let space for equivocation.

The VAT law should take into account activities with importance for the community regarding the determination of the rate of the VAT, as is the case for example the food industry.

Since, Albania seeks to integrate in the EU, the VAT law should be changed in accordance with Directive 2006/112 / EC of the Council of Europe, dated 28 November 2006 "On the common system of value added tax".

The new draft law on the VAT is being drafted by the new albanian government in accordance with Directive 2006/112 / EC of the Council of Europe.

\section{References}

[1] Law No. 9920 Dated. 19.05.2008 "On Tax Procedures in the RA"

[2] Instruction of the Ministry of Finance No.24 dated 02.09.2008 "On Tax Procedures in the RA."

[3] Law No. 7928 dated 27.4.1995 "On Value Added Tax in the RA."

[4] Instruction of the Ministry of Finance No.17 dated 13.05.2008 "On Value Added Tax in the RA."

[5] Law no.9454, dated 21.12.2005 published in the Official Journal No.105, January 2006

[6] Law no. 9712 dated 16.04.2007, published in Official Journal no.54, 12.05.2007.

[7] Law no.10003 dated 06.10.2008, published in Official Journal no. 164, 22.10.2008

[8] Law no. 10144, dated 28.09.2009, published in Official Journal no. 144, 12.10.2009.

[9] Law no. 10363, dated 16.12.2010, published in Official Journal No. 181, December 2010.

[10] Law no. 111/2013, dated. 01/04/2013, published in the Official Journal No. 55, 17/04/2013.

[11] Law no. 142/2013, dated. 05/02/2013, published in the Official Journal. No. 83, 5/20/2013,

[12] Law no. 182/2013, dated. 28.12.2013, published in Official Journal no. 203, 12/30/2013.

[13] Instruction no. 5 dated. 31.01.2011, published in Official Journal no. 6, January 31, 2011.

[14] Instruction no. 26, no. 02.12.2011, published in Official Journal no. 165, dated 23.12.2011.

[15] Instruction no. 11, dated 14.05.2012,published in the Official Journal no. 59, 29.05.2012.

[16] Instruction Nr. 7, dated 6.02.2013, published in the Official Journal no. 9, February 14, 2013.

[17] Instruction Nr. 6, dated 02/27/2014, published in the Official Journal no. 27, March 10, 2014.

[18] Instruction no. 6/1, dated 17.03.2014, published in the Official Journal no. 32, 17.03.2014.

[19] Instruction no. 6/2, dated 03.04.2014, published in the Official Journal no. 44, April 7, 2014.

[20] Directive 2006/112 / EC of the Council, dated 28 November 2006 "On the common system of the value added tax".

[21] Comparative Analysis of the Value Added Tax (VAT) and Retail Sales Tax (RST): A Contribution

[22] to Tax Reform Studies in the U.S., Marcos Valadao. 


\title{
Fiscal Evasion and Shadow Economy: Albanian Case
}

\author{
Jonida Balliu \\ Bachelor of Banking-Finance \\ "Epoka" University \\ 2014
}

\begin{abstract}
Shadow economy includes economic activities and the income obtained due to avoidance of taxes. Fiscal evasion is one of three main parts of shadow economy. It is a problem present almost in every country in the world. It is very largely people's desire to evade taxes that creates most of the shadow economy. First of all, this thesis focuses on the factors which affect informal economy and different forms in which it is seen. Second part of this study is about fiscal evasion and shadow economy in Albania. It is analyzed the factors which have helped in developing of informal economy in my country, by using evidences from different sources. in Albania section, it is also included a sub-section which focuses on the different ways that needs to be followed in order to fight against fiscal evasion. Shadow economy and fiscal evasion, cannot be completed eliminated, but all the countries should fight in order to reduce fiscal evasion, thus reducing the size of informal economy.
\end{abstract}

\section{Introduction}

Shadow economy is a major problem found in every country of the world, with different levels. in developing countries it gives a significant help to a more rapid economic growth. The shadow economy is greater in the Southern European countries than in other OECD countries (Hart, 1994). There exist different definitions about the shadow economy. According to Kelly, shadow economy refers to those economic activities that are not reported or not taxed (Schneider \& Friedrich, 2007) One of the definitions which is widely used and accepted by most of the people around the world is that shadow economy gives a relationship between unofficial (unreported) income and the measured income which is reported to tax authorities. According to this definition shadow economy includes all those activities which are unrecorded and provide a value for the economy of a country that should be present in the gross national product (GNP).

Shadow economy can be divided into three main parts:

Tax Evasion (Legally performed economic activities, but tax are not paid)

Black Economy (Legal activities are illegally performed)

Criminal Activities (Illegal activities)

Fiscal evasion is the use of illegal tactics to avoid financial liabilities. There are different ways to engage in fiscal evasion. The most common one is hiding or not declaring the incomes, thus resulting in reduction or avoidance of taxes. This allows people to keep more money for their purposes. Other ways to engage in fiscal evasion are reporting more expenses than really incurred, falsifying the accounts and not obeying the rules found on the article of the "Income-Tax Act". Such unethical practices often create problems for the tax evaders. Tax evaders are punished with different penalties like fines, prison or even the persecution of their belongings. There should be made a clear distinction between tax avoidance and tax evasion. Tax avoidance means performing the economic activities in a way that reduces taxes. Tax avoidance is legal, while tax evasion is illegal and as mentioned above it is punished. in order to prove the legality of tax avoidance the case is usually send to a court. As it is illegal those engaged in this activity have several reason to seek to conceal what they are doing. The formal economic theory of tax evasion can be dated at 1972, with the publication of the article "Income Tax Evasion", a theoretical analysis made by Allingham and Sandmo. (Allingham \& Sandmo, 1972).

According to Yitzhaki (1974) an increase in the tax rate increases the amount of reported income, and he also found in his research that the fine which will be paid by the tax evader will be proportional to the amount of evaded taxes. This model of Yitzhaki was not realistic, because all other researches were finding that when tax rate increase the amount of evaded taxes will be increased, too (Yitzhaki, 1974). Yitzhaki (1987) reworded this theory by arguing that the probability of being caught is positively related to the amount of unreported taxes. He concluded that an increase in tax rates increases tax evasion. Many other authors - like Gordon (1989); Klepper, Nagin, and Spurr (1991); Lee (2001); and Panades (2001) have conducted their searches in order to explain the contradiction between finding from the studies and theories. 
The presence of an underground sector is simply a reflection of individual's incentives to hide their economic activities, either because these activities would be less rewarding if practiced in the formal sector, or else because the activities are illegal to begin with. Understanding what factors might influence such incentives is an important subject of my thesis. By its nature, the shadow economy is difficult to study empirically. Whilst different approaches yield different estimates, the general conclusion is that the extent of informal economy is substantial. (SCHNEIDER \& ENSTE, 2002). The underground economy in Egypt, Thailand, and Nigeria, during 1998-1999 was estimated to be 69, 70, and 77 percent of official GDP, respectively. Amongst the developed countries, Greece and Italy have the largest shadow economies, estimated to be in the region of 27-29 percent of GDP during 1989-1999. The key factors that influence the underground economy have been related to aspects of public policy and public administration. Included among these are the burdens of taxation and social security contributions, the complexity of the tax system, the extent of bureaucracy and regulations. Functioning of financial markets has an important role to play in determining informal behavior. The recent studies about this are; First by DablaNorris and Feltenstein (2005) reports a significant negative correlation between measures of financial development and the size of shadow economy (Norris \& Feltenstein, 2005). The second study is by Straub (2005) that provides evidence of a significant positive effect of credit market efficiency on the degree of business formality.

Evidences of shadow economy in Albania were first seen in the years of transition to the market economy. This transition found Albanian economy with a significant level of lack of capital stock, and Albanians were seeking to change this situation as soon as possible. The collapse of pyramid schemes in 1996-1997 left a big gap between the real economy growth rate and institutional one.

\section{Evolution of Tax Structure}

Scholars of the historical evolution of tax structure like Hinrichs (1966) and Musgrave (1969) have stressed the importance of tax administration issues. They note that modern tax structure development has generally been characterized by a shift from excise, customs, and property taxes to corporate income and progressive individual income taxes. This shift has been made possible by the expansion of the market sector and relative decline of the rural sector, the concentration in larger establishments, and the growing literacy of the population. Changes in the technology of tax administration, including globalization financial innovation may shift from progressive income taxes toward tax system that rely more on broad-based consumption taxes such as value-added tax (VAT) and flatter rate structures for income taxation. Alt's (1983) treatment of the evolution of tax structure stresses the role of administrative costs. He argues that it has become easy to collect taxes from organized business rather than from households. Consideration of evasion, avoidance, and administration is essential to the positive and normative analysis of taxation. It is tax policy in action that determines how much the taxpayer must pay, and the effects of the payment. Knowledge of the statute is only a start in knowing a tax system. The interpretations placed on language by administrators and courts, the simplicity and understandability of tax reforms, and the competence of audit influence the amount of revenue collected and the economic effects of the tax.

\section{Evasion, Avoidance, and Real Substitution Response}

The distinguishing characteristic of evasion is illegality. Evasion is concerned with concealing or misrepresenting the nature of transaction, when avoidance takes place the facts of the transaction are admitted but they have been arranged in such a way that the resulting tax treatment differs from that intended by the relevant legislation (Fagbemi, Uadile, \& Noah, 2010). At times we will refer to real substitution responses, as those responses which come about because the tax law changes the relative price of different activities, and that induce taxpayers to respond by choosing a different consumption basket. Substitution responses are efforts to reduce one's tax liability without altering one's consumption basket, which we will refer to as avoidance. This definition covers a broad range of behaviors.

One example is to pay a tax professional to alert one to the tax deductibility of activities already undertaken.

Another example is to change a legal form of a given behavior, such as reorganizing a business from $A$ corporation to a $B$ corporation.

A third example is tax arbitrage, when economically equivalent, but differentially taxed. 


\section{Literature Review}

The concept of the informal economy was first introduced during an empirical study conducted regarding urban labor markets in Ghana (Hart, 1973) by ILO since then it has frequently been used by ILO in other studies and by World Bank reports in studies regarding poverty in developing countries (Sethuraham 1981, Mazumdar 1981). Term of "informal economy" was firstly used as a way of describing dualistic economic structure found in developing countries. There have been used different terms to refer to informal economy. It has been called irregular economy (Ferman, 1973), black economy (Dilnot and Morris, 1981), shadow economy (Frey, Weck and Pommerehne, 1982; Cassel \& Cichy, 1986).

At ILC held in 2002, the term of "informal economy" refer to economic activities which are not legal and not recognized from the law, it also refers to revenues collected from unpaid or lucrative work. Schneider's definition of informal economy (2012) : "the shadow economy includes all market-based legal production of goods and services that are hidden from public authorities in order to avoid payment of income taxes (VAT or other taxes), to not pay social security, to avoid dealing with some bureaucratic procedures, such as completing statistical questionnaires or other administrative forms" .

The relation between corruption and shadow economy has been studied by many authors. They see these two elements as either complements or substitutes of each other. Both Johnson and Hidricks see corruption and shadow economy as complements of each other. According to Hidricks this happens in the cases where the tax payer agrees or corrupts the responsible person in of tax authorities to under report tax liabilities.

This relationship differs from countries with high income level and those with a low income level. in high income countries corruption is low. Corruption can be seen in case it is desired to benefit from an activity that makes the work easier, e.g. wining a contract from a public authority, getting a license.

In low income countries, we expect different situation. in these countries companies are almost fully engaged in informal activity. These can be restaurants, bars and even bigger production companies. The public goods provided by the official sector are in many developing countries less efficient as compared to high income countries.

Schneider in 2007 has stated that the informal economy is low in countries where the income level is high, while in countries with a lower income level informal economy is higher due to a larger percentage of corruption. in the first one there exists a substation effect between these two indicators, while in the second case these indicators are complement of each other.

Fiscal evasion was firstly studied by Allingham and Sandmo in 1972 (Allingham \& Sandmo, 1972). in their "portfolio" model the individual behaves in a way that takes the highest satisfaction from evading taxes, makes a balance of benefits of this action and the probability of being caught and then punished, and after this confrontation decides to pay the taxes fully or partially because is afraid of being detected. in their study they observed that the factors that affect tax evasion directly or indirectly affect the shadow economy as well, even though there is no congruence between fiscal evasion and shadow economy.

The model of tax evasion by Sandmo, Allingham and Yitzhaki assumes that tax payers decide how much to evade according to their income level, tax rate, probability of detection and penalty rate (Sandmo, 2005). According to an audit of TCMP (Taxpayer Compliance Measurement Program), in USA 1998, was found that the amount of unreported income from workers, working in someone else company, is lower than unreported income from self-employed ones. Another issue that arises from the analysis of fiscal evasion is the level of non-compliance income class. (Fiorio \& D'Amuri, 2005)

Tax evasion and trust in the institution are inversely related, the higher the trust in the institution the lower amount of taxes evaded. (Gërxhani, 2004).

In the process of paying taxes free-rider effect can be found. A tax payer will be more willing to pay the taxes 1 ) if it is believed that others will do the same, 2 ) if it is believed that government will keep its promises. As the trust in government institution and in other citizens' fall, tax evasion increases. The willingness to pay drops to zero or only the amount they believe can be detected and punished is being paid.

An increase in taxes increases the level of underground economy, thus increasing fiscal evasion. The influence of tax growth in informal economy has been emphasized by a number of empirical studies made by Schneider (1994) and Johnson (1998). This strong influence of tax growth in underground economy has been proven with the Austrian and Scandinavian cases. From studies that have been made it is found that when tax rate is increased the willingness to pay the taxes is decreased. (Clotfelter, 1983)

Perception of audit rates is another factor that affects the compliance of taxes, indirectly the level of shadow economy. Individuals appear to underestimate the probability of audits to be conducted. If a taxpayer believes that probability if an audit to happen is high, then the level of evasion will be decreased, due to fear of being caught. When audit rates increase 
by $10 \%$ the amount of reported income increase by $1 \%$ or even $2 \%$ (Witte and Woodbury, 1985; Dubin, Graetz, and Wilde, 1990). Fiscal evasion is sometimes ethical (Nasadyuk \& McGee, 2007). A study regarding this hypothesis was made in Ukraine by Irina Nasadyuk and Robert W. McGee. They conducted a survey and found that the view that tax evasion is somewhat ethical is prevalent for 17 out of 18 statements. Several psychological studies have concluded that tax evasion is found as ethical depending on the circumstances. According to Robert Pennock tax evasion is seen as ethical in case the country where this evasion takes place is in an unfair war. Empirical studies conducted in Argentina ,Bosnia \& Herzegovina, China, Germany, Guatemala, Poland, where the respondents were asked about the ethics of fiscal evasion, reached a common conclusion that tax evasion is justified depending in the circumstances. As study of Mexican migrant workers found that when people are somewhat rewarded for paying taxes, the probability of tax evasion to incur is lower.

\section{Methodology and Data}

This thesis is an analysis of fiscal evasion and shadow economy in Albania for 2000-2010. Data for this analysis are taken form Bank of Albania, World Bank, IMF, INSTAT and other national and international organizations.

As the scope of the project is very broad, there have been used different methods to better analyze the problem. One of them is the survey research. This method is important if we want to test the hypothesis stated below.

\section{Hypothesis}

Tax growth increases tax evasion.

Tax evasion will be higher when government is perceived to be corrupt.

Tax evasion is sometimes ethical

According to Spector (1981) and Denscombe (2003), by conducting a survey we can collect information from a large number of people and use this information to establish statistical significance. Since the study is about tax evasion population of the study was comprised of tax payers, business owners, sample was randomly selected. It is used the surveys made by different national and international organization, regarding informal economy in Albania.

For the aim of comparison of shadow economy and fiscal evasion in different countries it's used data from statistical institutions and international organization like: IMF (International Monetary Fund), World Bank, EBRD (European Bank for Reconstruction \& Development).

In order to measure the fiscal evasion, direct and indirect methods were used. These include: Auditing by tax authorities, which yield an estimate of the person real income, thus allowing them to better understand the level of fiscal evasion. An indirect way of measuring fiscal evasion is making a comparison of one's reported income and their expenditures, in budget surveys or in national income accounts. The data for measuring fiscal evasion were taken from other studies made before, but in the case of Albania the data were obtained from INSTAT, IMF etc

\section{Albanian Case}

The size of informal economy is a serious problem in Albania. It is seen as one of the main factors which prevent economical and political development of the country, as well as integration of Albania in European Union.

In the beginning of 1990's Albania left Communism system. This system had destroyed country's economy. in this period informal economy grew too much, due to lack of state structures and law. Informal sector helps economy grow in the short run, but is very dangerous in the long run. That is what happened to Albania.

\section{Factors of informal economy in Albania}

I am going to analyze the main factors which have affected the growth of informal economy in Albania.

Labor Market

Non-Declaration of Income

Corruption

Taxation System 


\section{Cash Economy}

\section{Labor Market}

Informal works as a labor market category. The Dual Labor Market Theory (Doeringer \& Piore 1971; Sant-Paul 1997) provides one approach to understanding the place of informal work within the labor market. It divides the labor market into four categories: primary, secondary, informal, and illegal. The authors argue that that these categories reflect the class, racial, and gender stratification in our society. The primary sector is regular, where wage jobs are taxed and regulated. The secondary sector is composed of jobs that have less security than primary work and are not well regulated, where I can mention lower wage jobs in the service sector. The Dual Labor Market Theory argues that the informal sector is composed of people who are not able to access primary or secondary work. Informal work includes people who operate their own small business in cash only or unregulated arrangement. The forth category is illegal work and that includes all criminal activity that is revenue generating.

\section{Diagram 1: Labor Market Categories}

$\begin{array}{llll}\text { Primary Sector } & \text { Secondary Sector } & \text { Informal Sector } & \text { Illegal sector } \\ \text { High wage } & \text { Low wage } & \text { Self-employment } & \text { Criminal } \\ \text { High security } & \text { Low security } & \text { Casual labor } & \text { Unregulated } \\ \text { Well regulated } & \text { Poorly regulated } & \text { Unregulated } & \end{array}$

Source: Cross \& Johnson, 2000

One problem with this typology is that it assumes discrete categories based on class, race or gender. Other research has found that many people who have easy access to the primary sector make the choice to engage in the informal economy, either as their primary source of income or as a means to generate supplemental income.

Labor market in Albania has undergone significant changes after 1990's. After 1990 a large group of people migrated to the western countries. Development of private sector goes uniformly with the development of informal economy. The working age population (15 and over) makes up approximately $88 \%$ of total population (INSTAT: Albanian Institute of Statistics, 2013).

In 2004 OECD conducted a research in Albania regarding the level of informal economy. They found out from their analysis that informal production in small enterprise sector was dominant over formal production. in the sectors of manufacturing, trade, transportation, construction, retailing and other service sectors the level of the informality is about $40 \%$ larger than the formal production. in other sectors such as public administration the scope for informal production is much more limited.

From the analysis made by OECD was measured that over the half ( $51 \%$ ) of value-added generated from the above sectors is informal.

\section{Unemployment}

in the end of 2011 unemployment rate was $13.1 \%$, by the end of 2012 it has reduced to $12.8 \%$. The highest percentage of unemployment is comprised of youth unemployment. According to INSTAT data, $64 \%$ of head of families are jobless. This is a critical point, as unemployment means less income per family, becoming a burden for the state. Because of this situation people engage in illegal activities, resulting in an increase of the size of informal economy. When applying for a job, most of organizations do not take their decisions on the basis of meritocracy; instead they use "references" from their friends or relatives. Even after 20 years of transition, unemployment remains one of the main factors of informal economy. 


$\begin{array}{lllll}\text { Year } & 2009 & 2010 & 2011 & 2012 \\ \text { Nr. of unemployed people } & 143340 & 143040 & 142950 & 141755 \\ \text { Unemployment rate } & 13.6 & 13.8 & 13.1 & 12.8\end{array}$

\section{Source: INSTAT}

Illegal employment is seen more in the following economic sectors:

Construction Sector

Small and medium size manufacture sector

Service Sector

Transportation

Trade

Private Fishing activity

\section{Non declaration of income}

Non-declaration of income is a wide spread phenomenon in Albania. Finding data about this topic is very difficult, as it is an informal activity.

Table2. Level of informal economy

\begin{tabular}{|c|c|c|c|c|c|c|}
\hline Year & 1999 & 2000 & 2001 & 2002 & 2003 & $\begin{array}{l}1 \mathrm{st} \text { hal } \\
2004\end{array}$ \\
\hline $\begin{array}{l}\text { Checked } \\
\text { Entities }\end{array}$ & 2421 & 33616 & 28988 & 40850 & 34117 & 1669 \\
\hline $\begin{array}{l}\text { Number of } \\
\text { employees } \\
\text { found }\end{array}$ & 9176 & 104119 & 101966 & 117943 & 115216 & 16943 \\
\hline $\begin{array}{l}\text { Illegal } \\
\text { employees } \\
\text { found }\end{array}$ & 3372 & 28060 & 22384 & 22564 & 18236 & 3798 \\
\hline$\%$ of Illegality & $36.7 \%$ & $26.9 \%$ & $21.9 \%$ & $19.2 \%$ & $20.1 \%$ & $22.4 \%$ \\
\hline $\begin{array}{l}\% \text { Informal } \\
\text { Economy }\end{array}$ & & $32.2 \%$ & $27.5 \%$ & $28 \%$ & $18.3 \%$ & $9.5 \%$ \\
\hline
\end{tabular}

Source: Trade-unions Research Institute Albania (2004)

From the above table we can see that the phenomenon of non-declaration of income is wide spread in Albania. Nondeclaration or under-declaration of income is positively related with the level of informal economy.

For example, in the 1st half of 2006 of 1669 checked entities the number of illegal employees was 3798 or $22.4 \%$.

There exists an under-declaration of wages and salaries in Albania. Companies usually under-declare wage levels, thus under-paying social securities. Employees working in these kinds of organization claim that it is better for them an immediate direct cash payment and neglect the future benefits of paying social securities.

Table3: Number of the registered economic activities and the number of declared employees 
from 2000 to the 1 st half of 2008.

$\begin{array}{lccccccccc}\text { Year } & 2000 & 2001 & 2002 & 2003 & 2004 & 2005 & 2006 & 2007 & \begin{array}{l}\text { 1st half } \\ 2008\end{array} \\ \begin{array}{l}\text { Registered in } \\ \text { SLI }\end{array} & 20564 & 26039 & 32132 & 40454 & 30408 & 30418 & 32541 & 33248 & 30232 \\ \begin{array}{l}\text { Declared } \\ \text { employees }\end{array} & 74511 & 92257 & 81121 & 75984 & 79897 & 82457 & 85467 & 86750 & 43177\end{array}$

Source: INSTAT

From an inspection made on the construction sector over years, illegality is found to be about $20-25 \%$, while informality at about $7-9 \%$. in SM manufacturing sector, it is found to be at a rate of $10 \%-15 \%$.

\section{Corruption}

Corruption is one of the biggest issues that Albanian government has to deal with. It is seen in different forms, like: giving gifts public officials, abusing with tenders, faulty privatization etc. Corruption is also related with organized crime. Because of corruption Albania's progress development has been hindered.

Table4. Estimates of corruption level in Albania

$\begin{array}{lllll}\% \text { of firms } & \% \text { of firms } & \% \text { of firms } & \% \text { of firms } & \% \text { of firms } \\ \text { expected to give } & \text { expected to } & \text { expected to give } & \text { expected to } & \text { expected to } \\ \text { gifts to public } & \text { give gifts in } & \text { gifts to secure } & \text { give gifts to get } & \text { give gifts to } \\ \text { official to "get } & \text { meeting with } & \text { government } & \text { an operating } & \text { get an import } \\ \text { thing done" } & \text { tax officials } & \text { contracts } & \text { license } & \text { license }\end{array}$

$\begin{array}{llllll}\text { Albania(2007) } & 57.7 & 22.4 & 30.5 & 10.9 & 21.8\end{array}$

Source: INSTAT 2007

The need for a better treatment explains why the public officials mostly paid are the doctors. According to different surveys that have been undertaken the $71 \%$ of the citizens that pay bribes pay to the doctors, where $47 \%$ to the nurses and $14 \%$ to the police officers. There are some reasons that push the citizens to make payments such as need to speed up a procedure, to receive a better treatment or to avoid a fine. From ten Albanian citizens eight interact at some point during the year with the public administration.

This type of corruption is seen more in rural areas than in suburban ones. Women are those who pay most of the bribes. These bribes are mostly paid on cash. in most of the cases $30 \%$ of bribes are paid by citizens themselves, $15 \%$ are given as a result of a request made by a third party for the public official. However, Albania has made a significant progress in the controlling of corruption.

\section{Taxation system}

Another very important factor affecting informal economy in a country is the taxation system. After 1997 Albania has undergone significant reforms in the taxation system. in Albania women tend to evade taxes less than men do (Gerxhani \& Kuiper, 2004). According to the results a survey, in Tirana $80 \%$ of the interviewed people do not pay any state taxes, only 
a few pay the social security payments in their formal employment. The payment of only one-third of this amount was provided by informal sector activities.

Level of tax evasion compared to a decade ago has been improved. Nowadays, tax evasion levels comprise mainly of nonpayment of taxes and duties, but also of unpaid insurance. (Mema \& Preci, 2003). There is a tax of only 10 percent on duties from income in my country. Despite this low tax rate there is still a high level of informality in Albania.

A major problem seen in the taxation system is the failure to declare the financial system. Companies manipulate their asset values in balance sheet.

According to a study conducted by ACER (Albanian Center for Economic Research) in 1999 in Albania, which was made to find the level of tax evasion in domestic and foreign companies operating in Albania, found that out of 87 respondents: (ACER: Albanian Center for Economic Research, 1999)

- $75 \%$ of companies admitted that tax evasion is a widely used practice.

- $73 \%$ of companies admitted that they do not report their real profit level.

Another problem that shows malfunction of taxation system is the failure to collect incomes.

The fault for this malfunction fall both on the tax-payers and tax authorities. Tax-payers have lost the faith on tax authorities, as a result of the briberies paid to them. They consider it unfair for them to pay the taxes, while others by giving some gifts to public officials avoid paying taxes. What is important for well functioning of tax system is a well-qualified staff. An informal sector $30 \%$ above of GDP implies negative consequences for collection of tax revenues.

\section{Cash economy}

Albania is a cash economy. Credit cards are rarely used in Albania. They are usually accepted at major hotels in Tirana, large shopping centers, and at some international airline offices. Checks also are rarely used, but they can be changed at banks, but only in large cities. The use of cash helps increase the level of informal economy in the country. The mentality of the people has also helped in favoring cash economy. People think that by using cash, their money is safer, than using credit cards when making a transaction. One of the problems that arise from the use of cash in every transaction is money laundering. People prefer to use cash in their transactions because they want to avoid the frustrating long procedures and controls by authorities. This way the origin of the money cannot be proved. Banking infrastructure is another factor that has favored the use of cash. Most of the banks are concentrated in the larger cities.

\section{How to fight fiscal evasion}

I believe that there are several ways to combat fiscal evasion in Albania. First of all the quality of audits need to be increased. This can be done through an improvement in tax audit methodologies and existing topics, creating a unique database with the results of inspections made on businesses and individuals. Strengthening of financial control may also help in the reduction in the size of informal economy. We should develop business management tools for a more precise control or a database including taxpayer's taxpaying habits.

Fiscal evasion can be reduced also by the improvement of enforcement procedures.

In order to control tax evasion government should:

Build business- friendly policies

Abolish repressive practices against business and fiscal arbitrariness

Increase cooperation between different state agencies

Increase the capacity and professionalism of customs and tax administration

Dr. Preci argues that in order to improve the control of fiscal evasion in the labor market it is required the education of both employees and employers; strengthening the legal and financial penalties for individuals and companies who manipulate company balance sheets.

\section{Conclusions}


This paper has explored a number of issues regarding shadow economy and fiscal evasion. Although in different levels and ways, shadow economy is present in every country. Tax evasion is an important and significant phenomenon that affects both developed and developing economies. Size of the informal economy and fiscal evasion associated with it should be clearly understood, in order to forecast the appropriate policies to deal with these issues. As it is mentioned above size of underground economy changes from country to country, even in developed countries like US or UK it comprises 10 percent of the measured economy. in less developed or developing countries, it goes up to 30-40 percent.

In this paper also is analyzed the relationship between corruption and the shadow economy. It is stated that informal economy and corruption are substitutes in countries with high income level. in countries which a have a low income level, corruption and informal economy are complements of each other.

I have also studied the relationship between tax rate, tax growth and the level of tax evasion. Generally countries with low tax rate, tend to have less fiscal evasion. However, Albania is an exception, since it has a low tax rate, but fiscal evasion is still a major problem. As the tax rate increase, the probability of evading taxes increases, too.

In the study about fiscal evasion I concluded, based on some researches, that fiscal evasion is somewhat ethical. It is seen as ethical in different situations like the case when human rights are abused, etc.

Fiscal evasion and size of informal economy is expected to increase if government is perceived as corrupted. Tax payers lack trust on governmental institution, so they evade taxes or pay only the amount they believe they can be caught.

An important part of the thesis was the relation between the income level and the compliance of taxes. There exists a positive relationship between these two factors. As income falls the under-reported income level also falls.

As a conclusion, I would say that shadow economy and fiscal evasion, cannot be completely eliminated, but all the countries should fight in order to reduce fiscal evasion, thus reducing the size of informal economy.

\section{References}

[1] (1999). ACER: Albanian Center for Economic Research. Tirana: NA.

[2] Allingham, M., \& Sandmo, A. (1972). Income Tax Evasion: A Theoretical Analysis. North-Holland Publishing Company , 20-25.

[3] Clotfelter, C. T. (1983). Tax Evasion and Tax Rates: An Analysis of Individual Returns. NA , 18-20.

[4] Fagbemi, Uadile, \& Noah. (2010). The Ethics of Tax Evasion. European Journal of Social sciences , 3-5.

[5] Fiorio, \& D'Amuri. (2005). Worker's Tax Evasion in Italy. NA , 15-16.

[6] Gërxhani, K. (2004). Tax Evasion in Transition . European Economic Reviw , 15-20.

[7] Gerxhani, K., \& Kuiper, E. (2004). Tax Evasive Behaviour and Gender in a Trabsition Country . NA , 14-19.

[8] Hart, A. (1994). Hidden Economy . NA, 10-12.

[9] INSTAT: Albanian Institute of Statistics. (2013). Registered Unemployment Rate , 30-35.

[10] Mema, \& Preci. (2003). On the Development of the Albanian Informal Economy. NA, 10-13.

[11] Nasadyuk, I., \& McGee, R. W. (2007). Ethics and Tax Evasion in Ukraine: An Empirical Study. NA , 25-30.

[12] Norris, D., \& Feltenstein. (2005). The Underground Economy and its Macroeconomic Consequences. NA , 1820.

[13] Sandmo, A. (2005). A theory of Tax Evasion: A retrospective view. National Tax Journal , 13-16.

[14] Schneider, \& Friedrich. (2007). Shadow Economy and Corruption All Over the World. NA, 17-20.

[15] SCHNEIDER, F., \& ENSTE, D. (2002). The Growth of the Underground Economy . International Monetary Fund , 5-10.

[16] Yitzhaki, S. (1974). Tax Avoidance, Evasion, and Admnistration. NA , 20-23. 